\title{
Soil Physical Properties as Predictors of Soil Strength Indices: Trinidad Case Study
}

\author{
Ronald Roopnarine $^{1}$, Gaius Eudoixe ${ }^{1 *}$, Derek Gay ${ }^{2}$ \\ ${ }^{1}$ Department of Food Production, University of the West Indies, St. Augustine, Trinidad \\ ${ }^{2}$ Department of Civil Engineering, University of the West Indies, St. Augustine, Trinidad \\ Email: *ronald.roopnarine@sta.uwi.edu
}

Received October 18, 2011; revised November 29, 2011; accepted December 11, 2011

\begin{abstract}
Characterizing soil engineering properties and analyzing their spatial pattern has a key role in managing soils for different land uses. A study was conducted to generate two soil engineering properties; shear strength (SS) and friction angle (FA) both related to slope stability from the database of soil agricultural indices. A total of 30 soils were analyzed in two batches of 15 for physicochemical and engineering properties. The first batch was subjected to correlation and regression analysis among properties, whilst the second was used to validate model predictions. Soil friction angle showed strong significant correlations with clay and sand percent. Further stepwise regression resulted in these two properties being the only predictors of peak and residual friction angle. None of the tested properties explained shear strength distribution among the soils. The validated model predicted friction angles for the larger database, which showed non-significant temporal differences from the present dataset used in this study. Spatially distribution of both peak and residual friction angles varied across Trinidad, higher friction angles being associated with higher slopes. Combination of this data with other spatial land attributes would greatly improve land management and slope stability prediction.
\end{abstract}

Keywords: Soil; Friction Angle; Engineering Properties

\section{Introduction}

Estimation of soil strength indices is required for the design of foundations, retaining walls, and pavements in civil engineering applications and for determining the resistance to traction and tillage tools in agricultural applications (Freudlund \& Vanapali, 2002) [1]. These indices are also essential in assessing the stability of slopes and soil, and can be used to construe the ability of a soil to withstand stresses and strains associated with naturally occurring instances of; increased pore pressure, cracking, swelling, development of slickensides, leaching, weathering, undercutting, and cyclic loading (Duncan \& Wright, 2005) [2] as well as anthropogenic changes to the landscape.

Shear strength and friction angle are two important soil strength indices which have not been given due attention, particularly in a country dominated by structurally weak and expanding soils (Brown and Bally, 1967) [3]. Locally, available soil information and spatial characterization have been centered on agricultural data. Soil physical and chemical data, along with profile descriptions are provided by Brown and Bally (1967) [3] and Smith (1983) [4] . Changing land use and development has

\footnotetext{
"Corresponding author.
}

seen alternative uses for this information with obvious limitations. Soil engineers rely on the existing soil physiochemical data and their theoretical relationships with engineering strength parameters to support and address land use decisions and slope stability issues. The need to estimate and spatially characterize these engineering based indices for a wide range of soils using a quick and reliable method is paramount to proper planning and management.

The difficulty and in some cases the high cost of attaining the soil strength indices has led to many researchers seeking correlations with easily measured soil index properties (Eid, 2006) [5]. Several empirical procedures have been developed over the years to predict the shear strength of soils, particularly unsaturated soils. Drained residual strength was shown to correlate with clay content as well as type of clay minerals (Stark \& Eid, 1997) [6]. The authors also showed strong correlations between drained residual strength and liquid limit. The soil water characteristic curve (SWCC) along with saturated shear strength parameters have been used to predict the shear strength of unsaturated soils (Vanapalli et al., 1996 [7]; Freudlund et al., 1996 [8]; Oberg \& Salfours, 1997 [9]; Khallili \& Khabbaz, 1997 [10]; Bao et al., 
1998 [11]). Other investigators suggested mathematical relationships such as elliptical and hyperbolic functions to predict the shear strength of unsaturated soils (Abramento \& Carvalho, 1990 [12]; De Campos \& Carillo, 1995 [13]; Escario \& Juca, 1989 [14]; Lu, 1992 [15]; Shen \& Yu, 1996 [16]; Xu, 1997 [17]).

Soil friction angle, which is a measure of the ability of a unit of soil to withstand a shear stress, is a derivative of the measurement of soil shear strength. It is the angle, measured between the normal force (confining stress) and the resultant force within the soil column (Coulomb, 1776) [18] that is attained when failure just occurs in response to a shearing stress. Peak soil friction angle refers to the initial angle attained from the initial shearing phase, while the residual friction angle refers to the angle obtained following the initial failure of the soil sample. Skempton (1964) [19], introduced the concept of residual strength and residual friction angle and proposed that it is this "softened strength" that governs the behavior of reactivated landslides and demonstrated that residual strengths as well as residual friction angles are typically much lower than their peak counterparts for clayey soils and that they consequently have a detrimental effect on longterm slope stability. The concept has since received considerable attention. Specifically, research efforts have focused on determining correlations between the residual friction angle of soils and soil indexes such as Atterberg limits, and clay fraction (Kaya \& Kwong, 2007) [20]. Harris et al. (1984) [21] proposed that specific engineering properties were related to particle size distribution and mineralogy. Tsiambaos (1991) [22] studied the influence of the variation in clay mineral content on the residual strength of soils and attempted correlations with clay size faction and plasticity index. Tugrul \& Zarif (1998) [23] showed that there were strong correlations between engineering properties of soils and particle size distribution and indicated that particle size distribution was more influential than mineralogy.

Relationships between engineering parameters and more specifically shear strength and friction angle with simple soil index properties vary across regions, which indicate a need for localized investigations. This study focused on identifying and modeling such relationships, across a wide range of soils.

\section{Methodology}

\subsection{Soil Selection and Sampling}

According to Suter (1960) [24] Trinidad is divided into five physiographic zones (northern range, northern basin, central range, southern range and southern basin), which provided the rationale for selecting a cross section of soils. A total of 15 soils were selected with at least two soil series in each zone to encompass the diversity of soil properties (Table 1). An additional 15 soils were selected following model development and used to validate the model. For each of the initial 15 soil series two types of samples were taken (disturbed and undisturbed) at a depth between $(1.6-2.0 \mathrm{~m})$. For the 15 soil series used for validation, only undisturbed samples were taken. Undisturbed samples were taken using a core (height $0.15 \mathrm{~m}$, diameter $0.073 \mathrm{~m}$ ) that was inserted vertically using a core sampler. The core sample was then sealed in plastic wrap and stored for laboratory analysis. Disturbed samples were collected using an auger and were prepared for subsequent laboratory analysis by air drying and grinding to pass a $2 \mathrm{~mm}$ sieve. Samples were stored in plastic containers until analyzed. In total $25 \%$ of the soil series were represented in the study.

\subsection{Laboratory Analysis}

\subsubsection{Disturbed Samples}

The disturbed samples were subjected to physical and chemical tests based on expected relationships with soil strength indices (Kaya \& Kwong, 2007 [20]; Harris et al., 1979 [21]) and available soil survey data. Six parameters were analyzed including; effective cation exchange capacity determined by the barium chloride method (Schwerdtfeger \& Hendershot, 2009) [25], pH determined potentiometrically in a soil to water ratio of $1: 1$ (Thomas, 1996) [26], particle size distribution determined using the hydrometer method (Gee \& Or, 2002) [27], Atterberg limits determined according to ASTM 2000a (McBride, 2000) [28], non-capillary void space and bulk density (Db) determined by (Brady \& Weil, 2002) [29].

Table 1. Physiographic zones, and families of the selected soils.

\begin{tabular}{|c|c|c|}
\hline Physiographic Zone & Soil Series & Family $^{\dagger}$ \\
\hline Northern Range & $\begin{array}{c}\text { San Souci } \\
\text { Anglais } \\
\text { Diego Martin } \\
\text { Maracas }\end{array}$ & $\begin{array}{c}\text { fine, mixed } \\
\text { clayey, kaolinitic } \\
\text { coarse-loamy, carbonatic } \\
\text { clayey, oxidic }\end{array}$ \\
\hline Northern Basin & $\begin{array}{c}\text { Piarco } \\
\text { Bejucal } \\
\text { River Estate }\end{array}$ & $\begin{array}{c}\text { clayey, kaolinitic } \\
\text { very-fine, mixed, acid } \\
\text { fine-loamy, micaceous }\end{array}$ \\
\hline Central Range & $\begin{array}{l}\text { Montserrat } \\
\text { Biche } \\
\text { Brasso } \\
\text { Marac }\end{array}$ & $\begin{array}{c}\text { fine, oxidic } \\
\text { very-fine, mixed } \\
\text { very-fine, montmorillonitic, } \\
\text { nonacid } \\
\text { very-fine, mixed }\end{array}$ \\
\hline $\begin{array}{l}\text { South Range and } \\
\text { Basin }\end{array}$ & $\begin{array}{c}\text { Princess Town } \\
\text { Moruga } \\
\text { Talparo } \\
\text { Ecclessville }\end{array}$ & $\begin{array}{c}\text { very-fine, montmorillonitic, } \\
\text { nonacid } \\
\text { fine-loamy, mixed } \\
\text { very-fine, mixed, acid } \\
\text { very-fine, mixed, acid }\end{array}$ \\
\hline
\end{tabular}




\subsubsection{Undisturbed Samples}

A modified version of the drained direct shear test (Vanapalli, 2002) [30] was used to determine shear strength. Soils were subjected to three vertical-confining stresses (0.5 normal stress, normal stress and 1.5 normal stress). The modifications involved using a constant shear rate on all samples of $0.35 \mathrm{~mm} \cdot \mathrm{min}^{-1}$ and a constant series of confining stresses. This was done to ensure that all the samples were exposed to similar stresses throughout the experiment and to ensure that there was consistency in the process. A plot of the maximum shear stresses versus the vertical (normal) confining stresses for each of the tests was produced. From the plot, a straight-line approximation of the Mohr-Coulomb failure envelope curve was drawn. The drained direct shear tests allowed the determination of peak and residual shear strength and friction angle respectively. This was conducted on all 30 undisturbed soils. The initial fifteen (Table 1) were used in model development, the remaining 15 where used to validate the model.

\subsection{Statistical Analysis and Model Development}

Person's product moment correlations were performed to determine variable colinearity and to aid in the selection of predictive variables, of soil strength parameters. Variables were subjected to a stepwise regression to determine the best model for predicting FA and SS that contained statistically significant, intuitively meaningful predictive variables. Only data elements that contributed significantly $(\mathrm{P}<0.05)$ to predicting FA and SS and that contributed greater than $5 \%$ to the overall improvement of the $\mathrm{R}^{2}$ were included in the equations. Where significant relationships were observed the models were used to generate FA and SS from the entire Brown and Bally (1966 [31], 1967 [3]) database. To account for temporal variability of parameters, the generated data was statisti- cally compared to Brown and Bally, (1966 [31], 1967 [3]) for the respective soil series at the study depth, using $t$ tests. The model was further validated with an independent dataset by comparing measured versus predicted values using Pearson's correlations. The generated data was then used to produce geospatial engineering maps. Categories for friction angle were determined based on the range and standard deviation (SD) of the data.

\section{Results}

\subsection{Characterization Data}

The range in properties of sampled soils used to develop the prediction equations for SS and FA are shown in Table 2. A broad variation in taxonomical classification was seen, with differences in mineralogy and lithology, necessary criteria for validity and reliability. Normality tests indicated that the data was normally distributed.

The clay and sand contents ranged from 27.2 - 94.3 and $1.74 \%$ - $56.7 \%$ respectively. Similar broad variation was seen for most soil properties, especially where correlated to sand or clay (Table 3). Two soils showed alkaline $\mathrm{pH}$ values, whilst $53 \%$ of the sampled group were strongly to extremely acid. Plastic and liquid limits ranged from 16.6 - 33.3 and $17.4 \%$ - $79.6 \%$ respectively. A notable difference was observed between Anglais and Piarco series which are both described as clayey, kaolinitic but showed contrasting plastic index values, the latter being much higher (23.2\%). Significant positive correlations were observed between plastic limits, ECEC and particle distribution (Table 3), with values for the former two properties increasing with increasing clay content. Capillary void space as well as bulk density was typical for mineral soils and showed minimal variation. The two properties were negatively correlated. Unexpectedly, ECEC showed no relation to clay or sand content, but ranged from $5.44-39.6 \mathrm{cmol}^{+} \cdot \mathrm{kg}^{-1}$.

Table 2. Predictive soil properties used in developing SS and FA regression equations.

\begin{tabular}{|c|c|c|c|c|c|c|c|c|}
\hline Soil Series & $\mathrm{pH}$ & ECEC & Clay & Sand & PL & LL & NCVP & $\mathrm{Db}$ \\
\hline & & $\mathrm{cmol}^{+} \cdot \mathrm{kg}^{-1}$ & & & $\%$ & & & $\mathrm{~g} \cdot \mathrm{cm}^{-3}$ \\
\hline San Souci & 6.36 & 21.4 & 34.0 & 44.7 & 26.7 & 39.0 & 6.65 & 1.39 \\
\hline Anglais & 4.18 & 5.44 & 27.2 & 56.7 & 16.6 & 17.4 & 12.3 & 1.36 \\
\hline Diego Martin & 6.86 & 12.5 & 34.6 & 47.1 & 25.0 & 22.5 & 7.99 & 1.37 \\
\hline Maracas & 3.85 & 11.6 & 62.1 & 25.5 & 26.3 & 63.7 & 10.9 & 1.46 \\
\hline Piarco & 3.45 & 14.3 & 39.6 & 51.6 & 23.2 & 56.5 & 10.8 & 1.47 \\
\hline Bejucal & 3.95 & 20.2 & 94.3 & 1.74 & 25.0 & 64.5 & 1.73 & 1.17 \\
\hline River Estate & 6.78 & 16.9 & 40.9 & 44.9 & 28.6 & 38.3 & 9.16 & 1.31 \\
\hline Montserrat & 6.07 & 35.0 & 44.7 & 37.0 & 27.7 & 40.6 & 7.53 & 1.42 \\
\hline Biche & 7.71 & 18.7 & 51.6 & 26.2 & 23.1 & 30.8 & 3.45 & 1.06 \\
\hline Brasso & 6.98 & 19.8 & 58.3 & 28.2 & 31.3 & 50.8 & 5.13 & 1.53 \\
\hline Marac & 4.01 & 22.8 & 58.3 & 29.2 & 33.3 & 43.5 & 6.95 & 1.34 \\
\hline Princess Town & 7.3 & 39.6 & 79.2 & 13.4 & 33.3 & 79.6 & 12.9 & 1.20 \\
\hline Moruga & 4.54 & 25.5 & 52.5 & 33.4 & 26.0 & 39.9 & 12.4 & 1.39 \\
\hline Ecclessville & 3.56 & 16.8 & 69.4 & 16.5 & 33.2 & 36.8 & 3.46 & 1.53 \\
\hline
\end{tabular}


Table 3. Correlations between soil properties and FA and SS.

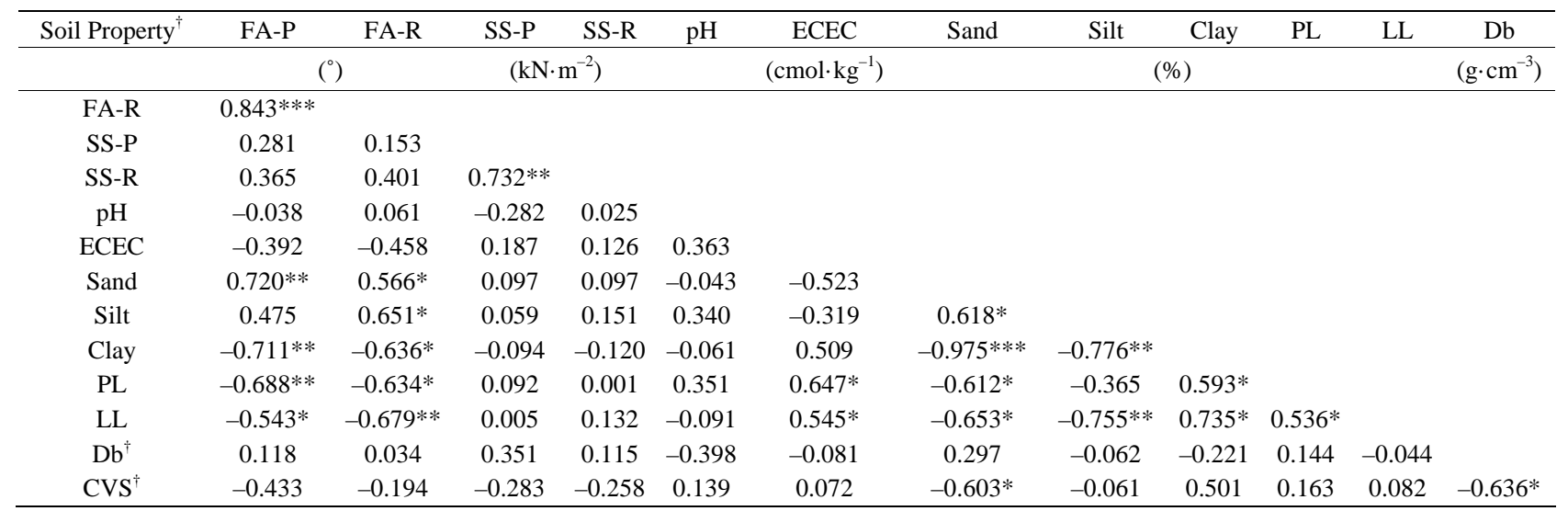

\subsection{Soil Engineering Properties and Model Development}

Peak SS ranged from $27.8-49.7 \mathrm{kN} \cdot \mathrm{m}^{-2}$ with a SD of $6.61 \mathrm{kN} \cdot \mathrm{m}^{-2}$ whilst peak FA ranged from $11.7^{\circ}-43.5^{\circ}$ with a SD of $10.2^{\circ}$ (Table 4). Peak FA showed strong and significant $(\mathrm{P}<0.01)$ positive and negative correlations with sand $(\mathrm{R} 2=0.720)$, and clay $(\mathrm{R} 2=-0.711)$ and PL $(\mathrm{R} 2=-0.688)$ respectively. Similarly significant but less strong relationships were seen for residual FA. Soil physiochemical variables showed no relationship with either peak or residual SS.

Table 5 shows the results of $t$ tests used to compare \% clay and sand of the study data set and Brown and Bally (1966, [31] 1967 [3]). There was no significant difference between the data set. Further correlation analysis revealed significant $(\mathrm{P}<0.05)$ positive relationships between these two data sets with $R^{2}$ values of 0.747 and 0.731 for clay and sand respectively. This validated the use of Brown and Bally (1970), data set to generate predicted values for peak and residual FA.

Clay and sand content explained $80 \%$ and $70 \%$ of the variation in the peak and residual FA of the data set respectively. The following regression equations were developed:

$$
\begin{aligned}
& \text { FA-P }=24.5-0.159 \% \text { clay }+0.357 \% \text { sand } \\
& F A-R=92.8-0.886 \% \text { clay }-0.723 \% \text { sand }
\end{aligned}
$$

Measured versus predicted peak and residual FA values for Equations (1) and (2) regression models are shown in Figures 1(a) and (b). The 95\% confidence intervals about the slope and intercept of the regression line for prediction of both peak and residual FA, indicate no significant difference from unity (Table 5). Peak and residual FA prediction equations values compared against the measured independent data set resulted in an $\mathrm{R}^{2}$ of 0.93 and 0.60 respectively.

The generated peak and residual FA data were converted to spatial coordinates and are shown in Figures 2 and 3 respectively. Colour codes identify FA categories
Table 4. Measured soil strength (SS) and friction angle (FA) of selected soils used in developing predictive equations.

\begin{tabular}{ccccc}
\hline Soil Series & SS-P & SS-R & FA-P & FA-R \\
\hline \multicolumn{4}{c}{$\mathrm{kN} \cdot \mathrm{m}^{-2}$} \\
San Souci & 43.9 & 35.8 & 41.8 & 37.9 \\
Anglais & 42.8 & 34.1 & 43.5 & 35.6 \\
Diego Martin & 39.3 & 28.3 & 33.8 & 25.9 \\
Maracas & 45.7 & 38.7 & 25.9 & 20.3 \\
Piarco & 48.6 & 30.6 & 39.9 & 15.5 \\
Bejucal & 27.8 & 20.2 & 11.7 & 10.5 \\
River Estate & 31.8 & 23.7 & 28.0 & 21.5 \\
Montserrat & 45.1 & 30.6 & 27.0 & 20.3 \\
Biche & 41.1 & 31.8 & 31.0 & 28.8 \\
Brasso & 32.4 & 26.0 & 21.4 & 19.3 \\
Marac & 43.5 & 38.9 & 19.0 & 16.5 \\
Princes Town & 45.1 & 37.0 & 15.5 & 9.1 \\
Moruga & 49.7 & 30.1 & 14.3 & 12.7 \\
Talparo & 47.4 & 33.5 & 16.7 & 11.7 \\
Ecclessville & 47.7 & 29.1 & 24.8 & 21.5 \\
\hline
\end{tabular}

Table 5. Statistical indices of $t$ tests for difference between data sets for regression variables.

\begin{tabular}{ccccccc}
\hline Data Set & \multicolumn{3}{c}{ Sand } & \multicolumn{3}{c}{ Clay } \\
\hline & Mean & SE & P & Mean & SE & P \\
Our Study & 29.6 & 4.4 & & 57.5 & 5.5 & \\
Brown and Bally (1970) & 27.6 & 4.9 & & 60.9 & 6.2 & \\
\hline
\end{tabular}

shown in association with soil series. Greater friction angles are associated with soils of the northern range and basin with the lower values within the central range and southern basin. Areas depicted in white represent regions for which no data was available which in most cases represented reclaimed land.

\section{Discussion}

\subsection{Characterization Data}

The initial characterization of soil physiochemical prop- 
erties focused on indices with known relationships with engineering properties. Particle size distribution, effective cation exchange capacity (ECEC) and Atterberg limits have all been shown to be related to soil strength properties (Kenney, 1967 [32]; Voight, 1973 [33] and Stark and Eid, 1997 [6]) however, the relationships have been specific to location. Correlation results were consistent with previous work done on these soils (Eudoxie, 2010 [34]; Brown and Bally, 1966 [31], 1967 [3], 1970 [35] \& K. V. Ramana, 1992 [36]). Strong positive correlations and insignificant $t$ test differences between our data set and that of Brown and Bally (1966 [31], 1967 [3], and 1970 [35]) indicated that these tested properties were temporally constant and ideal for use as predictive variables.

Notwithstanding the aforementioned finding, the results also revealed some anomalies. ECEC and clay content, showed non-significant correlations, which is contrary to the general consensus in the literature. This may be explained by the stronger influence of clay mineralogy on ECEC than clay content as evident by the findings of Kulkarni, (1972) [37]. The Maracas series which contained $60 \%$ clay, had an ECEC of $11.6 \mathrm{cmol}^{+} \cdot \mathrm{kg}^{-1}$. The soils of the Northern Range including Maracas are high in kaolinite, with minor amounts of montmorillonite, illite, and vermiculite (M. Sweeney, 1981) [38]. Kaolinite is a 1:1 mineral with low CAC (cation adsorption capacity). The Piarco series showed an unusually high PL, especially when compared to other soils within the same family. This is attributed to the depth at which the sample was taken (1.6 - $2.0 \mathrm{~m})$. In the Piarco series clay accumulates at that depth, due to eluviation and illuviation processes (Brown \& Bally, 1970) [35]. The Atterberg limits are important indicators of a soil's ability to withstand deformation or stress at various moisture contents. Odell et al. (1960) [39] indicated that values of plastic and liquid limits all increased with clay content and proportion of 2:1 expanding minerals. They showed strong correlations between liquid limit, plastic limit, and plasticity index, respectively, and three soil properties na-

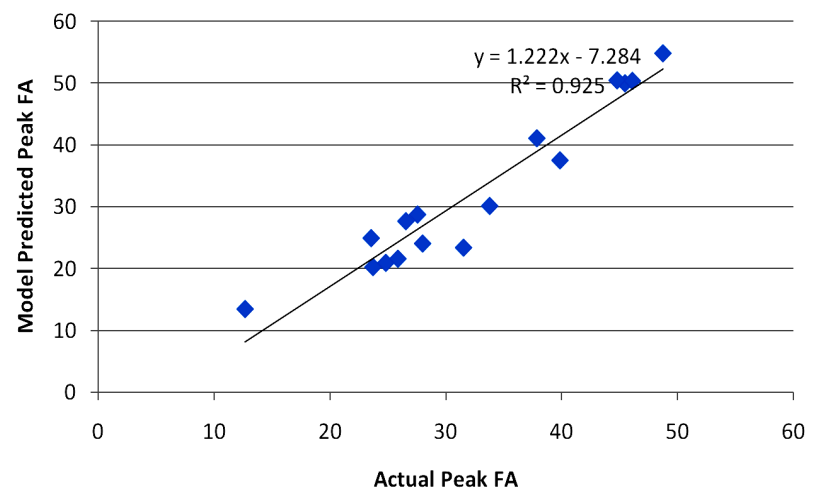

(a) mely, percent of organic carbon, percent of clay, and percent of montmorillonite in the clay separate. Seybold et al (2008) [40] additionally reported that clay content and CEC explained $81 \%$ of the variation in LL of a very large data set $(n=6592)$. Similar findings are reported herein, with clay and ECEC showing the greatest $\mathrm{R}^{2}$ values for LL and PL of respectively.

\subsection{Soil Engineering Properties}

SS showed limited variation compared to friction angle among soil series. According to the Mohr coulomb failure criterion, the former is a derivative of the friction angle and other mathematically related variables. The low SS values of 27.8 and $31.8 \mathrm{kN} \cdot \mathrm{m}^{-2}$ for the Bejucal and River Estate series, can be attributed to low internal friction angle and negligible cohesion of the former soil. This is consistent with the work of Kenney, (1967) [32], Lupini et al. (1981) [41] and Skempton (1985) [42]. Bejucal and Talparo both show low internal friction angles but widely different peak shear strengths, this may be due the mineralogy and percentage clay being more influential on shear strength than on FAs as well as the over consolidated nature of the latter which may have prevented the soil from being fully drained and hence matric suction would have contributed to the shear strength value. As expected the residual strength was lower than the peak shear strength for all soil series sampled as explained by Skempton (1964) [19].

Friction angles varied from $9.1^{\circ}$ to as high as $37.92^{\circ}$. The lower FAs were associated with soils that from central and southern zones, which could explain the high degree of slumping and sliding, associated with the clays of that region (Kanithi et al. 2006) [43]. A strong negative correlation with clay content reaffirms the previous inference, since these soils had higher clay contents. Friction angles are equivalent to the angle of repose of loose materials, implying a frictional resistance, which is low in clay particles (Skempton, 1964) [19]. Residual friction

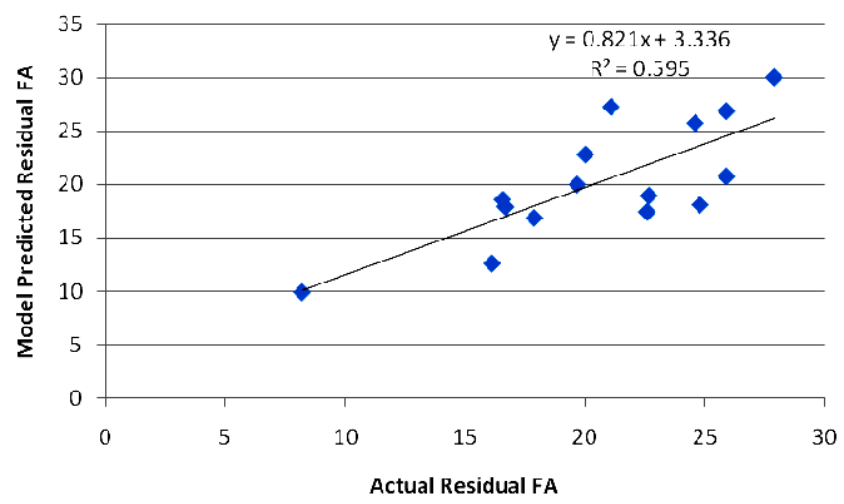

(b)

Figure 1. (a) Showing model prediction vs actual peak FAs; (b) Showing model prediction vs actual residual FAs. 


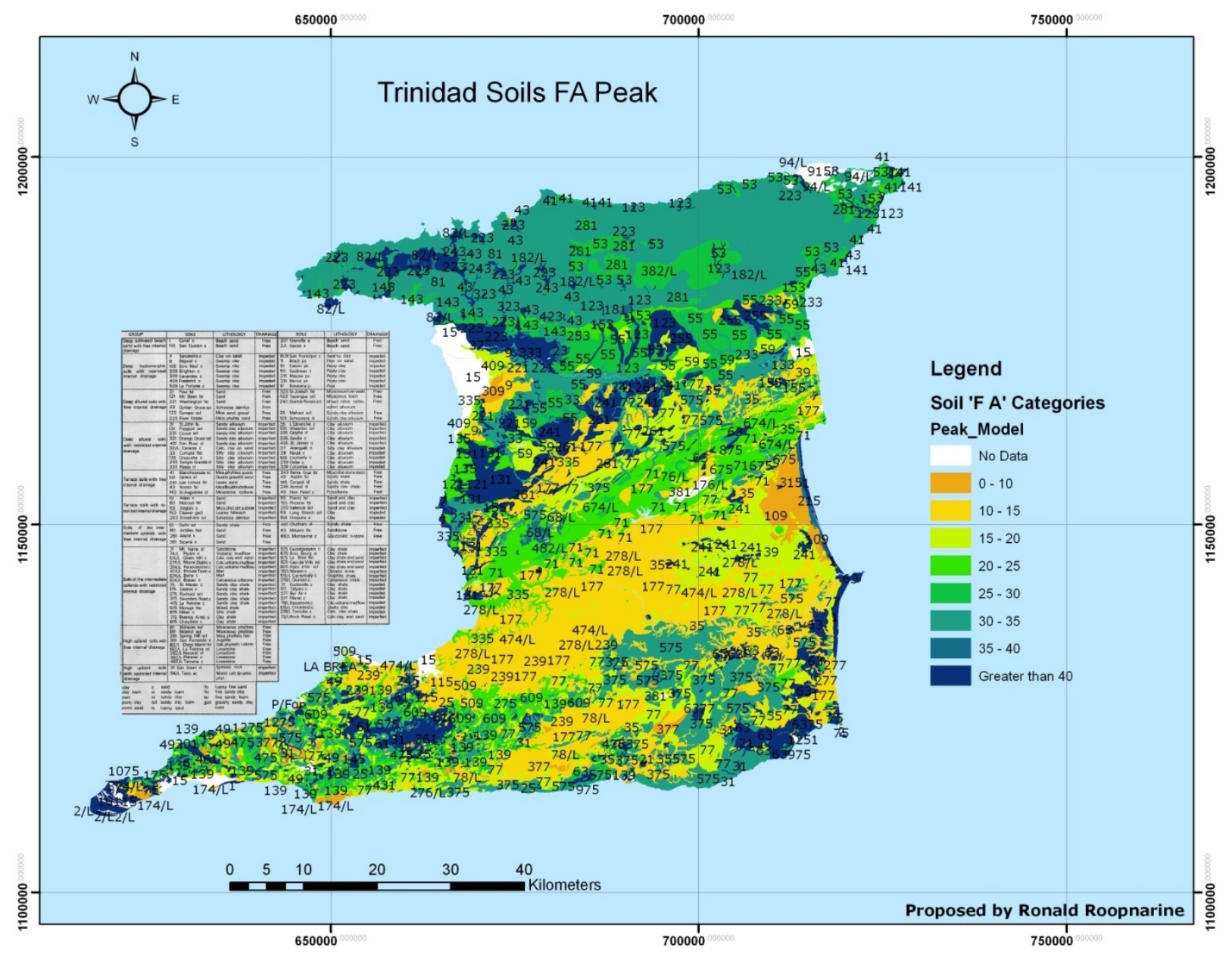

Figure 2. Soil map of Trinidad showing spatial distribution of peak friction angle categories.

angles like residual strength were all lower for all soil which indicates that once soil aggregates are disturbed it is much easy for particles especial clays to move, realigning themselves and reducing friction (Skempton 1964) [19]. The soils of the northern range showed the higher friction angles than the soils of the other zones due to their higher sand content and shallow depth, exposing unconsolidated material at the sampling depth.

The results of this study were consistent with the work of Tugrul \& Zarif (1998) [23] and Seybold et al. (2008) [40], which showed that there were strong correlations between engineering properties of soils and particle size distribution, and that particle size distribution was more influential, than mineralogy. This inference is supported by the non-significant relationship of CEC to percent sand and clay and soil strength indices. Kulkarni (1972) [37] indicated that CEC is more strongly associated with clay mineralogy, than clay content. The data indicates that the influence of soil properties such as the Atterberg limits on SS and FA were masked by their relationship to the primary properties of sand and clay. Statistically signifycant indicator properties were identified only for FA, which supports the Mohr Coulomb failure criteria, FA is a constant soil feature. Contrastingly shear strength is influenced by both spatial and temporal dynamic features such as moisture content and vegetation (Haines, 1925) [44].

Validation results justified the use of the prediction equation. Seybold et al. (2008) [40] reported similar confidence in the predictive models for Atterberg limits.

Generation of FAs for the soils of Trinidad plus their geospatial distribution provides a valuable asset and resource for not only engineering uses but also natural resource and disaster management specifically landslide/ mass movement susceptibility mapping. FAs were categorized in small intervals (5 - 10 degrees) to ensure precise spatial representation. The lower FAs ( 0 - 20 degrees) are associated with greater potential for slope instability and soil movement especially when subjected to increase moisture which decreases suction pressure between individual soil particles (Krahn et al. 1989) [45]. However, a significant proportion of the soils with low FAs are located on flat to slightly sloping terrain, supporting the need to use this data in combination with other soil and 


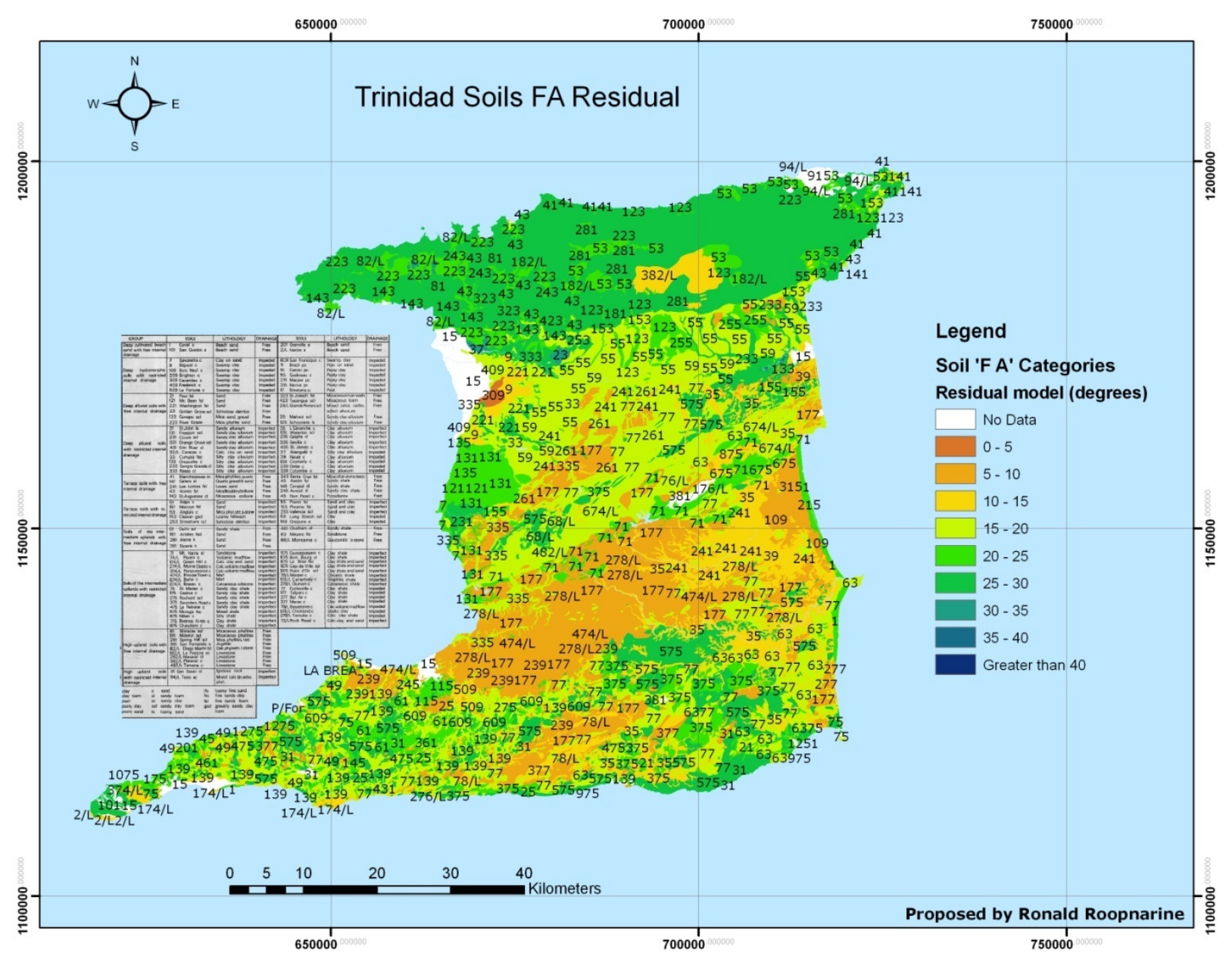

Figure 3. Soil map of Trinidad showing spatial distribution of residual friction angle categories.

physical data. Combining the FA data with other available soil survey data like slope class, can provide critical information, useful for land and engineering design evaluation. Having such data readily available also reduces on the lengthy, expensive and time consuming laboratory testing needed to estimate these soil strength indices.

\section{Conclusion}

Sand and clay content were the most highly correlated and the only independent variables in predicting FA. None of the index properties evaluated showed any relationship to SS, however there were many correlations among these index properties. Strong prediction equations were generated for peak and residual FA, with $\mathrm{R}^{2}$ values of 0.80 and 0.70 respectively. Validation trials confirmed the accuracy and reliability of the models. Transformation of the Brown and Bally (1966 [31], 1967 [3], 1970 [35]) dataset resulted in production of a geospatial representation of peak and residual FAs of Trinidadian soils. Where testing capabilities are limited, this map may provide a useful tool along with other available soil survey information. This study sets the stage for generating relevant engineering data in geospatial mode much like what already exists for agricultural purposes.

\section{REFERENCES}

[1] D. G. Freudlund and S. K. Vanapalli, "Shear Strength of Unsaturated Soils,” Agronomy Society of America, 2002, pp. 329-361.

[2] J. M. Duncan and S. G. Wright, "Soil Strength and Slope Stability,” John Wiley \& Sons, New York, 2005.

[3] C. Brown and G. Bally, "Land Capability Survey of Trinidad and Tobago. No. 4. Soils of the Northern Range of Trinidad,” Government Printery, Port-of-Spain, 1967.

[4] G. Smith, "Soil and Land Use Survey No. 27, Correlation of the Commonwealth, Caribbean, Puerto Rico, Virgin Islands and Guyana,” August Publication, Farnham, 1983.

[5] H. T. Eid, "Factors Influencing the Determination of Shale Classification Indices and Their Correlation to Mechanical Properties," Geotechnical and Geological Engineering, Vol. 24, No. 6, 2005, pp. 1695-1713. doi:10.1007/s10706-005-5726-2

[6] T. D. S. Eid and T. Hisham, "Drained Residual Strength 
of Cohesive Soils,” Journal of Geotechnical Engizeering, Vol. 121, No. 9, 1997, pp. 335-343.

[7] S. K. Vanapalli, D. G. Fredlund, D. E. Pufahl and A. W. Clifton, "Model for the Prediction of Shear Strength with Respect to Soil Suction," Canadian Geotechnical Journal, Vol. 33, No. 3, 1996, pp. 379-392.

doi:10.1139/t96-060

[8] D.G. Freudlund, S. K. Vanapalli and D. E. Pufahl, “The Relationship between the Soil-Water Characteristic Curve and the Shear Strength of a Compacted Glacial Till,” Geotechnical Testing Journal, Vol. 19, No. 3, 1996, pp. 259-268. doi:10.1520/GTJ10351J

[9] A. Oberg and G. Salfours, "Determination of Shear Strength Parameters of Unsaturated Silts and Sands Based on the Water Retention Curve," Geotechnical Testing Journal, Vol. 20, No. 1, 1997, pp. 40-48. doi:10.1520/GTJ11419J

[10] N. Khalili and M. H. Khabbaz, "A Unique Relationship for $\mathrm{x}$ for the Determination of the Shear Strength of Unsaturated Soils," Geotechnique, Vol. 48, No. 5, 1997, pp. 681-687. doi:10.1680/geot.1998.48.5.681

[11] C. G. Bao, B. Gong and L. Zan, "Properties of Unsaturated Soils and Slope Stability of Expansive Soils," 2nd International Conference on Unsaturated Soils, Beijing, 27-30 August 1998.

[12] M. Abramento and C. S. Carvalho, "Geotechnical Parameters for the Study of Natural Slope Instabilization at Serra do Mar-Brazilian Southeast," Proceeding of the 12th International Conference on Soil Mechanics and Foundation Engineering, Rio de Janeiro, Vol. 3, 1990, pp. 1599-1602.

[13] T. M. P. De Campos and C. W. Carillo, "Direct Shear Testing on Unsaturated soils from Rio de Janerio," Proceeding of the 1st International conference on an unsaturated soil, Paris, 6-8 September 1995, pp. 31-38.

[14] V. Escario and J. F. T. Jucá, "Strength and Deformation of Partially Saturated Soils," Proceedings of the 12th International Conference on Soil Mechanics and Foundation Engineering, Rio de Janeiro, Vol. 2, 1989, pp. 43-46.

[15] Z. Lu, "The Relationship of Shear Strength to Swelling Pressure for Unsaturated Soils," Chinese journal of geotechnical engineering, Vol. 14, No. 3, 1992, pp. 1-8.

[16] Z. Shen and S. Yu, "The Problems in the Present Studies on Mechanics of Unsaturated Soils," Proceedings of the Symposium on Geotechnical Aspects of Regional Soils, Atomic Energy Press, Beijing, 1996.

[17] Y. Xu, "Mechanical Properties of Unsaturated Expansive Soils and Its Application to Engineering,” Ph.D Thesis, Hohai University, Nanjing, 1997.

[18] C. A. Coulomb, "Essai sur une Application des Regles des Maximis et Minimis a Quelquels Problemesde Statique Relatifs, a la Architecture,” Mem. Acad. Roy. Div. Sav, Vol. 7, 1776, pp. 343-387.

[19] A. W. Skempton, “4th Rankine Lecture: Long-Term Stability of Clay Slopes,” Géotechnique, Vol. 14, No. 2, 1964, pp. 77-101. doi:10.1680/geot.1964.14.2.77

[20] A. Kaya and K. P. Kwong, "Evaluation of Common Practice Empirical Procedures for Residual Friction Angle of
Soils: Hawaiian Amorphous Materials Rich Colluvial Soil Case Study,” Engineering Geology, Vol. 92, No. 1-2, 2007. doi:10.1016/j.enggeo.2007.03.002

[21] W. G. Harris, L. W. Zelazny, J. C. Parker, J. C. Baker, R. S. Weber and J. H. Elder, "Engineering Properties of Soils as Related to Mineralogical and Particle-Size Variables,” Soil Science Society of America Journal, Vol. 48, 1984, pp. 978-982. doi:10.2136/sssaj1984.03615995004800050005x

[22] G. Tsiambaos, "Correlation of Mineralogy and Index Properties with Residual Strength of Iraklion Marls,” Engineering Geology, Vol. 30, No. 3-4, 1991, pp. 357-369. doi:10.1016/0013-7952(91)90068-V

[23] A. Tugrul and I. H. Zarif, “The Influence of Mineralogical Textural and Chemical Characteristics on the Durability of Selected Sandstone in Istanbul, Turkey," Bulletin of Engineering Geology and the Environment, Vol. 57, No. 2, 1998, pp. 185-190. doi:10.1007/s100640050034

[24] H. Suter, "The General and Economic Geology of Trinidad, BWI,” Colonial Geology and Mineral Resources: The Quarterly, HMSO, 1960.

[25] D. Schwertfeger and W. Hendershot, "Determination of Effective Cation Exchange Capacity and Exchange Acidity by a One-Step BaCl2 Method," Soil Science Society of America, Vol. 73, No. 2, 2009, pp. 737-743. doi:10.2136/sssaj2008.0009

[26] G. W. Thomas, "Soil pH and Soil Acidity,” In: R. S. L. Sparks and D. L. Swift, Methods of Soil Analysis. Part 3-Chemical Methods, Soil Science Society of America, 1996, pp. 475-490.

[27] G. Gee and D. Orr, "Particle-Size Analysis," Method of Soil Physical Analysis, Soil Science Society of America, 2002, pp. 278-281.

[28] R. McBride, "Methods of Soil Analysis: Physical," Soil Science Society of America, 2000.

[29] R. N. C. Brady and R. Weil, "The Nature and Properties of Soils,” 13th Edition, Prentice-Hall, London, 2002.

[30] S. K. Vanapalli, “A Simple Technique for Determining the Shear Strength of Fine-Grained Unsaturated Soils using the Conventional Direct Shear Apparatus,” 2nd Canadian Specialty Conference on Computer Applications in Geotechnique, Winnipeg, 28-30 April 2002, pp. 245-253.

[31] C. Brown and G. Bally, "Land Capability Survey of Trinidad and Tobago. No. 3. Soils of the Northern Range of Trinidad," Trinidad Government Printery, Port-ofSpain, 1966.

[32] T. C. Kenney, "Influence of Mineralogical Composition on the Residual Strength of Natural Soils," Shear Strength of Natural Soils and Rock, Oslo Geotech, Oslo, Vol. 1, 1967, pp. 123-129.

[33] B. Voight, "Correlation between Atterberg Plasticity Limits and Residual Strength of Natural Soils," Geotechnique, Vol. 23, 1973, pp. 265-267. doi:10.1680/geot.1973.23.2.265

[34] G. Eudoxie, "Nitrogen Enigma in Tropical Soils," VDM Verlag Dr. Muller Aketiengesellschaft \& Co. KG, Berlin, 2010. 
[35] C. Brown and G. Bally, "Land Capabilites Survey of Trinidad and Tobago. No. 5. Port-of-Spain,” Government Printery, Port-of-Spain, 1970.

[36] K. V. Ramana, "Humid Tropical Expansive Soils of Trinidad: Their Geotechnical Properties and Areal Distribution,” Engineering Geology, Vol. 34, 1992, pp. 27-44. doi:10.1016/0013-7952(93)90041-A

[37] K. Kulkarni and N. K. Savant, "Effect of Soil Compaction on Root-Cation Exchange Capacity of Crop Plants," Plant and Soil, Vol. 48, No. 2, 1972, pp. 269-278. doi:10.1007/BF02187239

[38] M. Sweeney, "A Mineralogical Study of Some West Indian Soil-Clays,” Thermochimica Acta, Vol. 48, No. 3, 1981, pp. 323-331. doi:10.1016/0040-6031(81)80253-5

[39] R. T. Odell, T. H. Thornburn and L. J. Mckenzie, "Relationships of Atterberg Limits to Some Other Properties of Illinois Soils,” Soil Science Society of America Proceedings, Vol. 24, No. 4, 1960, pp. 297-300. doi:10.2136/sssaj1960.03615995002400040025x

[40] C. A. Seybold, A. E. Moustafa and J. E. Robert, "Linear Regression Models to Estimate Soil Liquid Limit and Plasticity Index From Basic Soil Properties,” Soil Science,
Vol. 173, No. 1, 2008, pp. 25-34. doi:10.1097/ss.0b013e318159a5e1

[41] A. E. Lupini and P. R. Vaughan, "The Drained Residual Strength of Cohesive Soils,” Geotechnique, Vol. 31, No. 2, 1981, pp. 181-213. doi:10.1680/geot.1981.31.2.181

[42] A. W. Skempton, "Residual Strength of Clays in Landslides, Folded Strata and the Laboratory," Geotechnique, Vol. 35, No. 1, 1985, pp. 3-18. doi:10.1680/geot.1985.35.1.3

[43] V. Khanithi and C. Khanhai, "Breaking Frontiers and Barriers in Engineering," 4th LACCEI International Latin American and Caribbean Conference for Engineering and Technology (LACCET'2006), Puerto Rico, 21-23 June 2006.

[44] W. Haines, "Studies in the Physical Properties of Soils: I. Mechanical Properties Concerned in Cultivation," The Journal of Agricultural Science, Vol. 15, No. 2, 1925, pp. 178-200. doi:10.1017/S0021859600005669

[45] J. Krahn, D. G. Fredlund and M. J. Klassen, "Effect of Soil Suction on Slope Stability at Notch Hill," Canadian Geotechnical Journal, Vol. 26, No. 2, 1989, pp. 269-278. doi:10.1139/t89-036 